\title{
Dung beetles of the tribe Phanaeini (Coleoptera: Scarabaeidade: Scarabaeinae) from Roraima state, Northern Brazil: checklist and key to species
}

\author{
Thaynara L. Pacheco ${ }^{1,3}$ \& Fernando Z. Vaz-de-Mello ${ }^{2}$ \\ ${ }^{1}$ Universidade Federal de Mato Grosso, Instituto de Biociências, Programa de Pós-graduação em Zoologia, \\ Av. Fernando Correa da Costa, 2367, Boa Esperança, Cuiabá, MT, Brazil. \\ ${ }^{2}$ Universidade Federal de Mato Grosso, Instituto de Biociências, Departamento de Biologia e Zoologia, \\ Av. Fernando Correa da Costa, 2637, Boa Esperança, Cuiabá, MT, Brazil. \\ ${ }^{3}$ Corresponding author: Thaynara Lara Pacheco,e-mail: thay.lpacheco@gmail.com
}

PACHECO, T.L., VAZ-DE-MELlO, F.Z. Dung beetles of the tribe Phanaeini (Coleoptera: Scarabaeidade: Scarabaeinae) from Roraima state, Northern Brazil: checklist and key to species. Biota Neotropica. 15(2): e20140145. http://dx.doi.org/10.1590/1676-06032015014514

\begin{abstract}
Phanaeini comprises about 160 species in 12 genera restricted to the Americas. Since the diversity of this tribe remains little known in several regions of Brazil, this study presents a guide to its 13 species with presence in the biologically rich and largely unexplored state of Roraima: Coprophanaeus (Coprophanaeus) abas (MacLeay, 1819), C. (C.) dardanus (MacLeay, 1819), C. (C.) gamezi Arnaud, 2002, C. (C.) jasius (Olivier, 1789), C. (Megaphanaeus) lancifer (Linnaeus, 1767), Oxysternon (Oxysternon) conspicillatum conspicillatum Werber, 1801, O. (O.) durantoni Arnaud, 1984, O. (O.) ebeninum (Nevinson, 1890), O. (O.) festivum viridanum (Olsoufieff, 1924), O. (O.) silenus chicheryi Arnaud, 2001, Phanaeus (Notiophanaeus) bispinus Bates, 1868, P. (N.) bordoni Arnaud, 1996 (first record from Brazil), and Sulcophanaeus faunus (Fabricius, 1775). The species of Dendropaemon were not considered herein because the genus is presently under taxonomic revision.
\end{abstract}

Keywords: Inventory, Amazon, Guyana Shield.

PACHECO, T.L., VAZ-DE-MELLO, F.Z. Os besouros rola-bostas da tribo Phanaeini (Coleoptera: Scarabaeidae: Scarabaeinae) do estado de Roraima, Norte do Brasil: lista e chave para as espécies. Biota Neotropica. 15(2): e20140145. http://dx.doi.org/10.1590/1676-06032015014514

Resumo: Phanaeini abrange cerca de 160 espécies pertencentes a 12 gêneros restritos às Américas. Como a diversidade desta tribo permanece pouco conhecida em diversas regiões do Brasil, este estudo apresenta um guia de identificação das 13 espécies com registro de ocorrência no estado biologicamente rico e amplamente inexplorado de Roraima: Coprophanaeus (Coprophanaeus) abas (MacLeay, 1819), C. (C.) dardanus (MacLeay, 1819), C. (C.) gamezi Arnaud, 2002, C. (C.) jasius (Olivier, 1789), C. (Megaphanaeus) lancifer (Linnaeus, 1767), Oxysternon (Oxysternon) conspicillatum conspicillatum Werber, 1801, O. (O.) durantoni Arnaud, 1984, O. (O.) ebeninum (Nevinson, 1890), O. (O.) festivum viridanum (Olsoufieff, 1924), O. (O.) silenus chicheryi Arnaud, 2001, Phanaeus (Notiophanaeus) bispinus Bates, 1868, P. (N.) bordoni Arnaud, 1996 (que aqui é reportado pela primeira vez no Brasil), e Sulcophanaeus faunus (Fabricius, 1775). As espécies do gênero Dendropaemon não foram incluídas no trabalho por estarem em processo de revisão taxonômica.

Palavras-chave: Inventário, Amazônia, Escudo das Guianas.

\section{Introduction}

Dung beetles of the subfamily Scarabaeinae are primarily scavengers that feed mostly on carrion, animal excrement and decomposing fruits (Halffter \& Matthews 1966). Thus, such insects display a crucial role in the balance of several ecosystems, representing highly informative bioindicators regarding the conservation status of tropical environments (Halffter \& Favila 1993). Such a peculiar feeding biology renders to dung beetles enormous ecological importance, acting directly in the fertilization and renewal of the soil, in the biological control of agricultural pests and also as secondary seed dispersal (Nichols et al. 2008).
The tribe Phanaeini was introduced by Hope (1838) without further comments, and was defined in more details by Kolbe (1905) who, based on the cup-like shape of the antennal club and lack of protarsi, included in this group the following genera: Phanaeus MacLeay, 1819, Oruscatus Bates, 1870, Gromphas Brullé, 1837, Bolbites Harold, 1868, Dendropaemon Perty, 1830 and Megatharsis Waterhouse, 1891. Gillet (1911) added the genera Ennearabdus van Lansberge, 1874a and Pleronyx van Lansberge, 1874b (then spelled Pteronyx) to Kolbe's (1905) group, formally allocating it as a subtribe of Coprini. Thirteen years later, d'Olsoufieff (1924) removed Ennearabdus and Pteronyx (sic), included Diabroctis Gistel, 1857 (as its synonym Taurocopris 
d'Olsoufieff, 1924), Oxysternon Castelnau, 1840 and Tetramereia Klages, 1907 (then described as new as Boucomontius d'Olsoufieff, 1924). In addition, the same author splitted Phanaeus into five subgenera: Phanaeus, and the new taxa Sulcophanaeus, Coprophanaeus, Metallophanaeus and Megaphanaeus. Based on the system proposed by d'Olsoufieff, Edmonds (1972) elevated Sulcophanaeus and Coprophanaeus to genus level. Furthermore Edmonds (1972) described Mioxysternon as a subgenus of Oxysternon, and subgenera Paradendropaemon and Coprophanaeoides for the genus Dendropaemon. More recently, Edmonds (1994) described Notiophanaeus as a subgenus of Phanaeus and Arnaud (2002) described Pteroxysternon as a subgenus of Oxysternon.

Geographically restricted to the New World, the tribe Phanaeini includes around 160 species and 12 genera allocated in the subtribes Phanaeina and Gromphadina (Cupello \& Vaz-de-Mello 2013). Phanaeini systematics is yet in discussion. In the field of alpha taxonomy, taxa of the group have been the subject of recent taxonomic revisions and of much discussion regarding validity of several species and subspecies (Arnaud 1996, 1996b, 1997, 2000, 2001, 2002, 2002b, 2002c, 2004, Edmonds 1994, Edmonds \& Zídek 2004, 2010, 2012, Cupello \& Vaz-de-Mello 2013, 2013b, Kohlmann \& Solís 2012). Phylogenetic studies are scarce and the debate regarding the identity of the tribe is still open. Zunino $(1983,1985)$ failed to recover Phanaeini as a clade, allocating its 12 genera to the tribe Onitini (Gromphadina [then spelled Gromphina] + (Onitina + Phanaeina)); in contrast, Philips et al. (2004) recovered a monophyletic Phanaeini supported by 14 morphological synapomorphies. One less inclusive approach by Price (2007) based on 67 morphological characters suggests that the genera Phanaeus and Oxysternon are not reciprocally monophyletic. Based on morphological and molecular data, Price (2009) recovers Phanaeus as polyphyletic, with representatives of Coprophanaeus, Sulcophanaeus, and Oxysternon nested within its terminals. Finally Tarasov \& Génier (2015) recover Phanaeini as monophyletic with the genus Ennearabdus appearing as its sister group forming Neotropical clade.

The Brazilian state of Roraima lies on the Guiana Shield, northern South America. In terms of natural landscapes, Roraima is highly heterogeneous; while dense Amazonian forests predominate in the southern portion of the state, open savannah spots locally referred by 'lavrados' are common in central Roraima. In contrast, mountainous formations characterize the northern area of the state, where there is the Pacaraima range, the geographic divisor of the Amazonas and Orinoco basins. Such a geomorphological plasticity is evidently associated to an enormous complexity of microhabitats, rendering Roraima a high biodiversity of animals and plants (IBGE 1977).

According to Vaz-de-Mello (2000), the diversity of dung beetles of Roraima is poorly known; considering all trustworthy records, there are only 47 Scarabaeinae species documented in the state. Nonetheless, considering the ecological importance of the group, the knowledge on the scarab diversity and the availability of tools allowing precise identification of species are crucial to provide proper support to future studies of conservational concern. Herein we provide a detailed inventory of the Phanaeini species occurring in the limits of the Roraima state, presented as a checklist of species containing detailed geographic data, as well as a key to species and an illustrated guide.

\section{Materials and Methods}

We examined specimens from the following entomological collections (acronyms in parentheses): Setor de Entomologia da Coleção Zoológica da Universidade Federal de Mato Grosso, Departamento de Biologia e Zoologia, Cuiabá, Mato Grosso, Brasil (CEMT), Coleção de Invertebrados do Instituto Nacional de Pesquisas da Amazônia, Manaus, Amazonas, Brasil (INPA), and Patrick and Florent Arnaud private collection, Saintry sur Seine, France (CPFA). In addition, we performed an extensive investigation of the literature approaching South American Scarabaeine (species descriptions, taxonomic revisions and regional inventories) computing all trustworthy records attributed to Roraima localities.

\section{Results and Discussion}

We reported 13 species of the tribe Phanaeini from localities within the limits of the state of Roraima (Table 1), since the publication of the most recent studies making reference to

Table 1. Checklist of Phanaeini species known to occur in Roraima.

\begin{tabular}{lc}
\hline Species & Record \\
\hline $\begin{array}{l}\text { Coprophanaeus (Coprophanaeus) abas (MacLeay, 1819)* } \\
\text { Coprophanaeus (Coprophanaeus) dardanus (MacLeay, 1819) }\end{array}$ & CEMT \\
& $\begin{array}{c}\text { Edmonds \& Zídek, 2010; Cupello \& } \\
\text { Vaz-de-Mello, 2013b; CEMT } \\
\text { Coprophanaeus (Coprophanaeus) gamezi Arnaud, 2002 }\end{array}$ \\
Coprophanaeus (Coprophanaeus) jasius (Olivier, 1789)* & Edmonds \& Zídek, 2010; CEMT; CPFA \\
Oxysternon (Oxysternon) conspicillatum conspicillatum Weber, 1801 & CEMT \\
Oxysternon (Oxysternon) durantoni Arnaud, 1984 & CEMT \\
Oxysternon (Oxysternon) ebeninum (Nevinson, 1890) & Arnaud, 2002; CEMT \\
Oxysternon (Oxysternon) festivum viridanum (Arnaud, 2002)* & Arnaud, 2002; CEMT; CPFA \\
Oxysternon (Oxysternon) silenus chicheryi Arnaud, 2001 & CEMT; INPA; CPFA \\
Phanaeus (Notiophanaeus) bispinus Bates, 1868* & Arnaud, 2001; CPFA \\
Phanaeus (Notiophanaeus) bordoni Arnaud, 1996* & CEMT \\
Sulcophanaeus faunus (Fabricius, 1775)* & CEMT \\
\hline
\end{tabular}

$*$ new state records. 
Table 2. New records of species of Phanaeini from Roraima, their localities and examined specimens.

\begin{tabular}{|c|c|}
\hline Species & $\begin{array}{l}\text { Examined specimens } \\
\text { from Roraima }\end{array}$ \\
\hline $\begin{array}{l}\text { Coprophanaeus (Coprophanaeus) } \\
\text { abas (MacLeay, 1819) }\end{array}$ & $\begin{array}{l}\text { BRASIL: Roraima: Amajari, Ilha de Maracá, IX-1996, Ribeiro \& Vaz-de-Mello } \\
\text { (CEMT: } 10,3 \uparrow q) \text {. }\end{array}$ \\
\hline $\begin{array}{l}\text { Coprophanaeus (Coprophanaeus) } \\
\text { jasius (Olivier, 1789) }\end{array}$ & 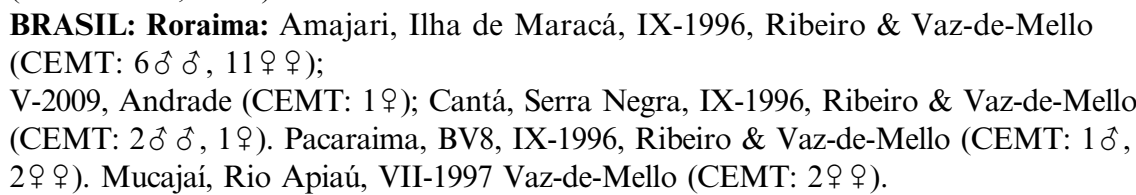 \\
\hline $\begin{array}{l}\text { Coprophanaeus (Megaphanaeus) } \\
\text { lancifer (Linnaeus, 1767) }\end{array}$ & 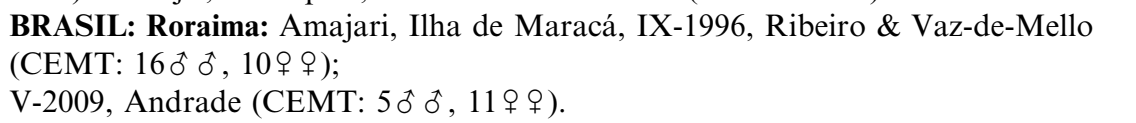 \\
\hline $\begin{array}{l}\text { Oxysternon (Oxysternon) } \\
\text { festivum viridanum } \\
\text { (Arnaud, 2002) }\end{array}$ & 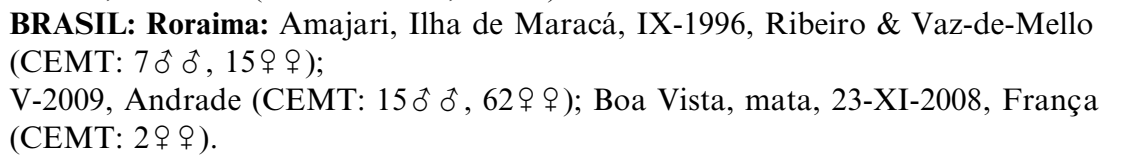 \\
\hline $\begin{array}{l}\text { Phanaeus (Notiophanaeus) } \\
\text { bispinus Bates, } 1868\end{array}$ & $\begin{array}{l}\text { BRASIL: Roraima: Amajari, Ilha de Maracá, IX-1996, Ribeiro \& Vaz-de-Mello } \\
\text { (CEMT: 1 } \text { ). }\end{array}$ \\
\hline $\begin{array}{l}\text { Phanaeus (Notiophanaeus) } \\
\text { bordoni Arnaud, } 1996\end{array}$ & BRASIL: Roraima: Amajari, Ilha de Maracá, V-2009, Andrade (CEMT: 1§). \\
\hline $\begin{array}{l}\text { Sulcophanaeus faunus } \\
\text { (Fabricius, 1775) }\end{array}$ & $\begin{array}{l}\text { BRASIL: Roraima: Amajari, Ilha de Maracá, IX-1996, Ribeiro \& Vaz-de-Mello } \\
\text { (CEMT: } 1 \precsim \text { ). }\end{array}$ \\
\hline
\end{tabular}

Roraima (Vaz-de-Mello 2000, Arnaud 2002, Edmonds \& Zídek 2010, Cupello \& Vaz-de-Mello 2013b).

Vaz-de-Mello (1999) mentioned Oxysternon (O.) durantoni as the first Phanaeini record to Roraima; two years later, Arnaud (2001) described $O$. (O.) silenus chicheryi from the confluence of the rivers Negro and Branco. Arnaud (2002) added $O$. (O.) conspicillatum conspicillatum, $O$. (O.) ebeninum and $O$. (Mioxysternon) spiniferum spiniferum as state records; however, the latter record is an error due to confusion of the abbreviations of the states Rondonia (RO) and Roraima (RR) (FZVM, personal observation in CPFA). In a taxonomic revision of Oxysternon, Edmonds \& Zídek (2004) synonymized O. festivum festivum and $O$. $f$. viridanum mentioning one specimen from Roraima. In the same year, Arnaud (2004) resurrected O. f. viridanum. After examining specimens from the same localities that based Edmond \& Zídek's (2004) decisions, we concluded that their record of Roraima shall be attributed to $O$. f. viridanum (sensu Arnaud, 2004). Edmonds \& Zídek (2010) added Coprophanaeus (C.) dardanus and C. (C.) gamezi as state records. Finally Cupello \& Vaz-de-Mello (2013) mention again $C$. (C.) dardanus.

In the holdings of CEMT, we recovered specimens of Coprophanaeus (C.) abas, C. (C.) jasius, C. (Megaphanaeus) lancifer, Oxysternon (Oxysternon.) festivum viridanum, Phanaeus (Notiophanaeus) bispinus, P. (N.) bordoni and Sulcophanaeus faunus, all representing new state records (Table 2). Oxysternon (Mioxysternon) spiniferum, Phanaeus chalcomelas, P. cambeforti, all widespread in Amazonia, were not recorded in our samples; nonetheless, we included these species in our identification key, considering its potential occurrence in Roraima, as well as the Phanaeini genera Gromphas and Dendropaemon.

\section{Key to the species of Phanaeini from Roraima}

1. Basal antennomere of antennal club not concave apically, two apical antennomeres not embraced by basal antennomere and clearly visible... Gromphas Brullé, 1837 (Figure 3GJ)

Basal antennomere of antennal club concave apically, two apical antennomeres embraced by basal antennomere (Figure 3F) ... 2

2. Mesotarsus and metatarsus with two or three tarsomeres (Figure 3M) ... Dendropaemon Perty, 1830

Mesotarsus and metatarsus with five tarsomeres ... 3

3. Clypeus anteriorly without strong emargination; if toothed, teeth external with respect to clypeal margin. Tooth of protibiae rounded ... 4

Clypeus with two acute teeth separated by a strong "V"shaped emargination, and with external emarginations separating them from adjacent clypeal border, producing the two acute external lobes. Protibiae with four strongly pronounced teeth... Coprophanaeus d'Olsoufieff, 1924 (Figure 1) ...6 6

4. Metasternum without spiniform process ... 5

Metasternum with curved spiniform process extending between apexes of procoxae... Oxysternon Castelnau, 1840 (Figure 2C) ... 10

5. Body very large (superior to $25 \mathrm{~mm}$ ) and with black color. Anterior margin of pronotum (circumnotal ridge) not interrupted behind each eye ... Sulcophanaeus faunus (Fabricius, 1775) (Figure 3KL)

Body size less than $25 \mathrm{~mm}$, dorsally with brown color or black with green or blue metallic reflections. Anterior margin of pronotum (circumnotal ridge) interrupted behind each eye ... Phanaeus (Notiophanaeus) Edmonds, 1994 ... 15

6. Very large, usually longer than $28 \mathrm{~mm}$. Elitral interstriae with strong transverse carinae. Dorsum color metallic, predominantly blue. Cephalic horn long and slightly tapering towards apex ... Coprophanaeus (Megaphanaeus) lancifer (Linnaeus, 1767) (Figure 1IJ)

Small to medium size, rarely exceeding $28 \mathrm{~mm}$. Elitral interstriae weakly convex, without strong sculpture. Varied 
Pacheco T. L. \& Vaz-De-Mello F. Z.

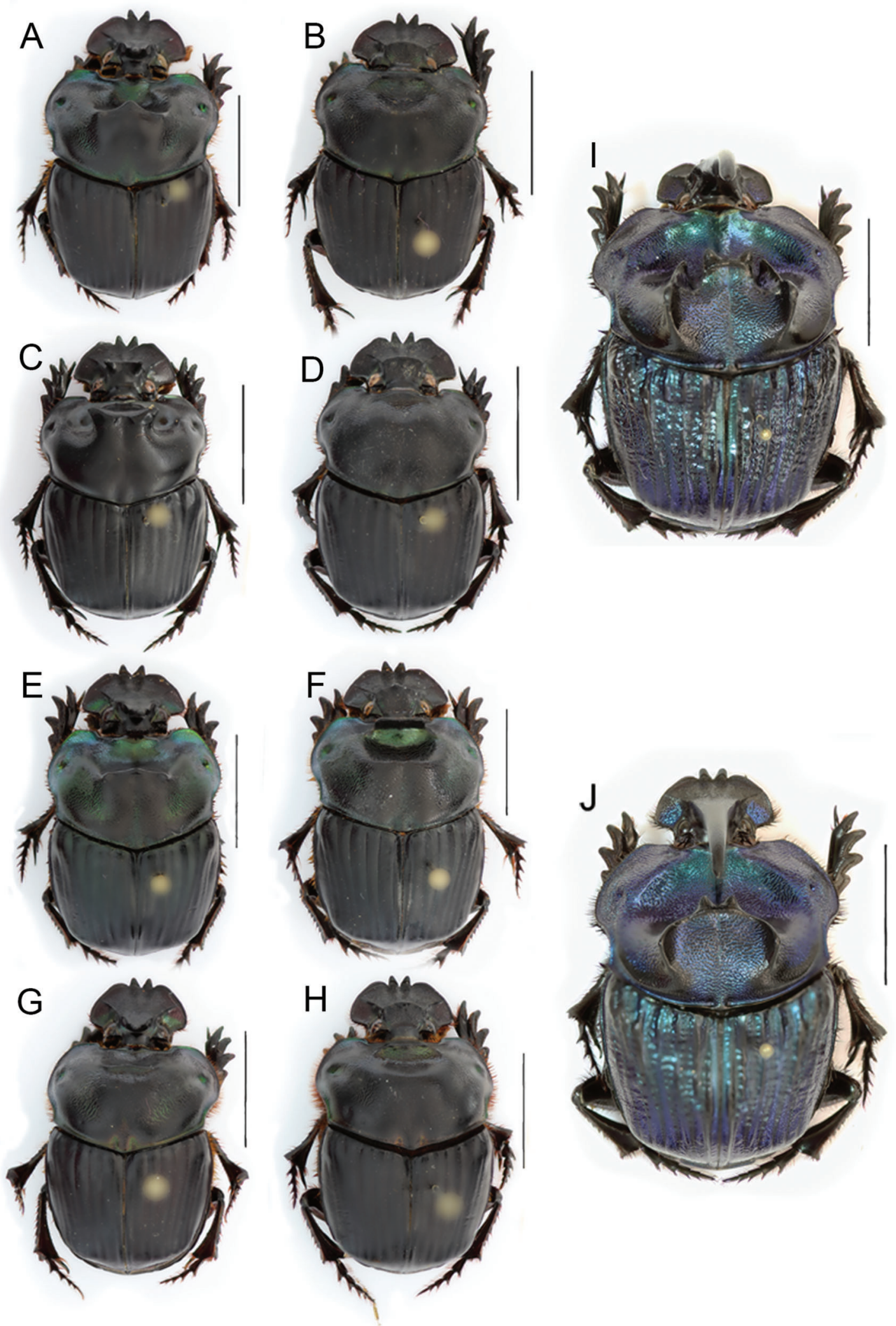

Figure 1. Species of the genus Coprophanaeus reported from Roraima: A - C. abas (male), B - C. abas (female), C - C. dardanus (male), D - C. dardanus (female), E - C. gamezi (male), F - C. gamezi (female), G - C. jasius (male), H - C. jasius (female), I - C. lancifer (male), J - C. lancifer (female). Scale bars $=10 \mathrm{~mm}$. 


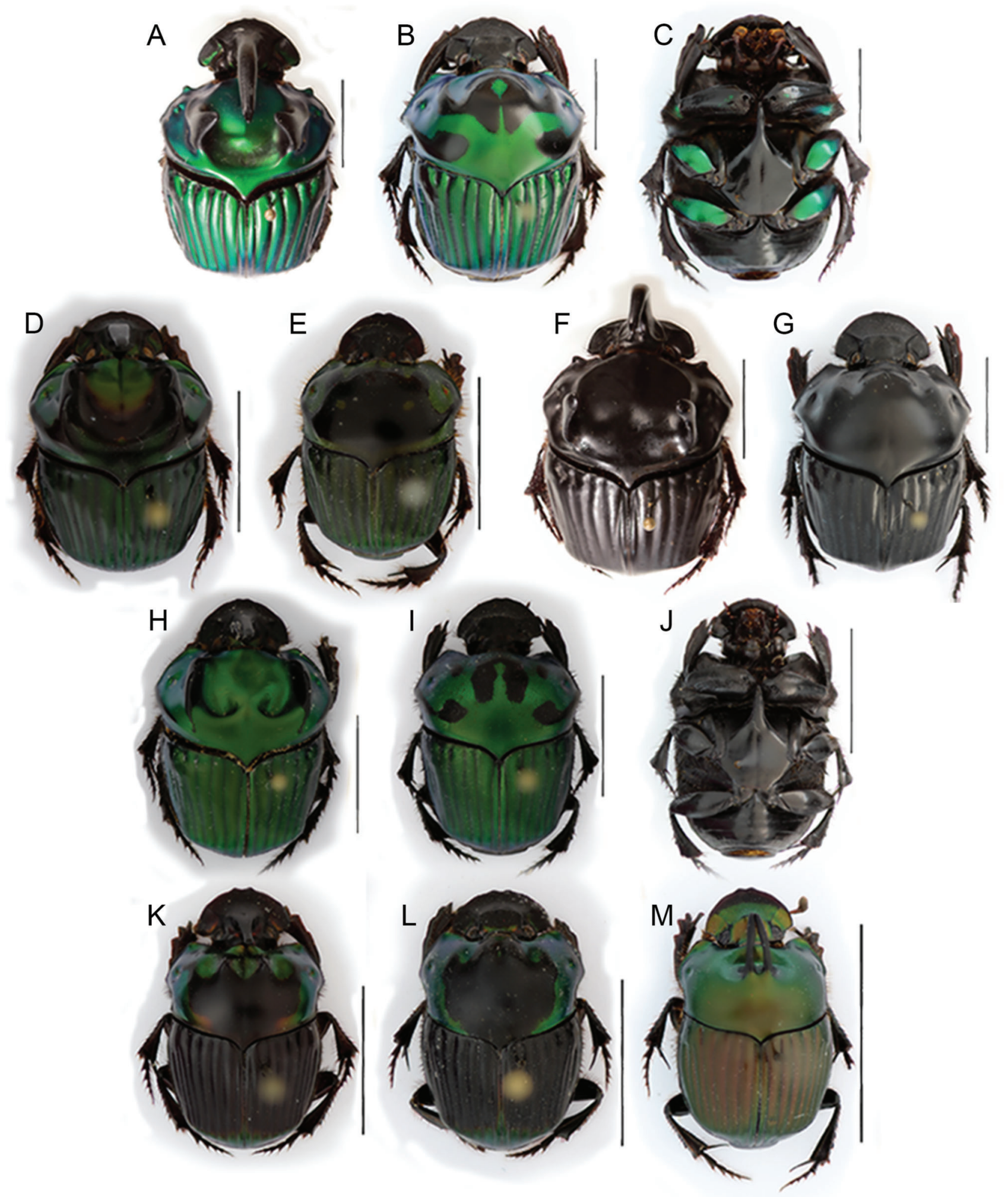

Figure 2. Species of the genus Oxysternon reported from or potentially occurring in Roraima: A - O. conspicillatum conspicillatum (male), B - O. conspicillatum conspicillatum (dorsal view, female), C - O. conspicillatum conspicillatum (ventral view, female), D - O. durantoni (male), E - O. durantoni (female), $\mathrm{F}$ - O. ebeninum (male), G - O. ebeninum (female), H - O. festivum viridanum (male), I - O. festivum viridanum (dorsal view, female), J - O. festivum viridanum (ventral view, female), $\mathrm{K}$ - O. silenus chicheryi (male), L - O. silenus chicheryi (female), $\mathrm{M}$ - O. spiniferum spiniferum (male). Scale bars $=10 \mathrm{~mm}$. 
Pacheco T. L. \& Vaz-De-Mello F. Z.
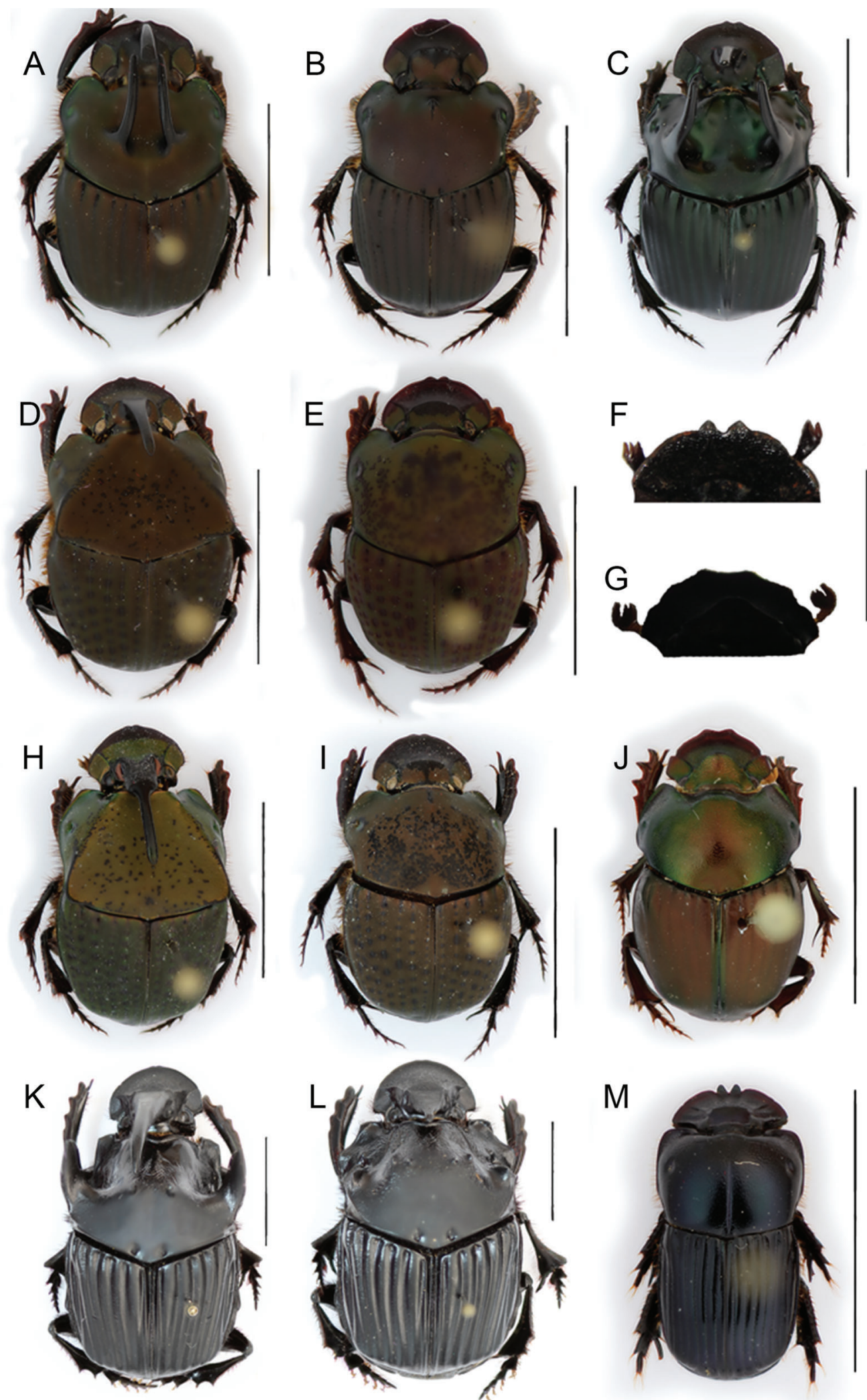

Figure 3. Species of the genera Dendropaemon, Gromphas, Phanaeus and Sulcophanaeus reported from or potentially occurring in Roraima: A - Phanaeus bispinus (male), B - P. bispinus (female), C - P. bordoni (male), D - P. cambeforti (male), E - P. cambeforti (female), F - anterior part of head of Dendropaemon viridipennis, G - anterior part of head of Gromphas sp., H - Phanaeus chalcomelas (male), I - P. chalcomelas (female), J - Gromphas aeruginosa, K - Sulcophanaeus faunus (male), L - S. faunus (female), M - Dendropaemon sp. Scale bars $=10$ mm. 
coloration, but elytra in the middle and posterior part of pronotum always black. Male cephalic horn laminate... Coprophanaeus (Coprophanaeus) d'Olsoufieff, 1924 .. 7

7. Anterior margin of pronotum (circumnotal ridge) interrupted behind each eye. Frontoclypeal carina of males rectangular, with two horns in extremes sides. Pronotum of males with strong bilobed projection, with an oval concavity at each side, below it; anterolateral portions strongly deep ... Coprophanaeus (Coprophanaeus) dardanus (MacLeay, 1819) (Figure 1CD)

Anterior margin of pronotum (circumnotal ridge) not interrupted behind each eye. Frontoclypeal carina of males with tritubercle horn. Pronotum of males with either one or three apical tubercles in central projection, anterolateral portions not deep ... 8

8. Posteromedian region of pronotum strongly punctured, especially between the fossae; pronotum of large males with three tubercles almost aligned; tubercles of females pronotum not distinct, only with a high ridge in anteromedian region. Species associated with savannah formations ... Coprophanaeus (Coprophanaeus) gamezi Arnaud, 2002 (Figure 1EF)

Posteromedian region of pronotum weakly punctured, smooth between the fossae. Species associated with forest formations, sympatrical ... 9

9. Pronotum of large males with central tubercle longer than lateral tubercles, triangularly expanded with an obtuse tip; in females anteromedian region of pronotum with a high transverse carina, rectangular in posterior view ... Coprophanaeus (Coprophanaeus) abas (MacLeay, 1819) (Figure 1AB)

Pronotum of large males with central tubercle not much larger than others, not triangularly expanded, small and with acute tip; in females anteromedial region with a high transverse carina, trapeziform in posterior view ... Coprophanaeus (Coprophanaeus) jasius (Olivier, 1789) (Figure 1GH)

10. Specimens longer than $15 \mathrm{~mm}$. Clypeus with one transversally oriented ventral carina... Oxysternon (Oxysternon) Castelnau, 1840 ... 11

Specimens up to $13 \mathrm{~mm}$ long. Clypeus without ventral carina ... Oxysternon (Mioxysternon) spiniferum Castelnau, 1840 (Figure 2M)

11. Elytra bicolored, dorsally black but with metallic posteriorad and laterad. Pronotum green with red metallic reflexes, generally with one black spot in its median region. Pronotum of males with two small tubercles ... Oxysternon (Oxysternon) silenus chicheryi Arnaud, 2001 (Figure 2KL)

Elytra unicolored, entirely green (except for striae that appear black in first glance) or black. Large males usually with two large tubercles in pronotum ... 12

12. Femora ventrally green. Elytra and pronotum also green, with black spots in female pronotum. Cephalic horn of males usually large and curved towards the median region of pronotum. Pronotum of males with one median depression forming two lateral carinae, and in the apex with two large tubercles curved towards the middle ... Oxysternon (Oxysternon) conspicillatum conspicillatum (Weber, 1801) (Figure 2ABC)

Middle and posterior femora ventrally black, other characters variable ... 13
13. Coloration uniformly black. Cephalic horn of males curved towards the median region of pronotum. Pronotum of males flat, with two large tubercles curved towards the middle region of pronotum ... Oxysternon (Oxysternon) ebeninum (Nevinson, 1890) (Figure 2FG)

Coloration metallic, at least elytra green, other characters variable ... 14

14. Size usually between 15 and $19 \mathrm{~mm}$. Pronotum and elytra always distinct in color, pronotum usually red at least in anterior region (black in the middle), elytra green with dark striae. Posterior region of abdomen metallic green ... Oxysternon (Oxysternon) durantoni Arnaud, 1984 (Figure 2DE)

Size usually between 18 and $25 \mathrm{~mm}$. Pronotum and elytra with the same color, except for black spots in the pronotal disc of females and small males. Ventral region totally black, including the posterior region of abdomen ... Oxysternon (Oxysternon) festivum viridanum d'Olsoufieff, 1924 (Figure 2HIJ)

15. Disc of pronotum of males never flattened, but either convex or strongly concave, with two projections directed towards the anterior region (Figure 3A) ... 16

Disc of pronotum of males flattened, without projections (Figure 3D) ... 17

16. Color dorsally brown. Pronotum of males with two median tubercles anteriorly directed. Elytra with striae strongly punctured ... Phanaeus (Notiophanaeus) bispinus Bates, 1868 (Figure 3AB)

Dark coloration, with green or blue reflex. Pronotum of males with two lateral tubercles, directed medially and then anteriorly. Elytral striae with very fine punctures if any ... Phanaeus (Notiophanaeus) bordoni Arnaud, 1996 (Figure 3C)

17. Anteromedial angle of metasternum capped. Basal third of cephalic horn of males abruptly expanded laterally. Pronotum of males with disperse black punctures; pronotum of females with a concavity, bearing an small anterior tubercle, a bigger posterior tubercle, and at each side with one lateral tubercle ... Phanaeus (Notiophanaeus) chalcomelas (Perty, 1830) (Figure 3HI)

Anteromedial angle of metasternum smooth. Cephalic horn of males not abruptly expanded. Pronotum of males with black punctures concentrated in posteromedian region; pronotum of females lacking concavity, with three central tubercles disposed approximately in a transverse row, sometimes the central one more anterior than lateral ones ... Phanaeus (Notiophanaeus) cambeforti Arnaud, 1982 (Figure 3DE)

\section{Acknowledgments}

We are indebted to Carolina S. Nardes, Guilherme A. P. C. Neves and Simoni E. da Silva for helping with data capturing of specimens and literature data; Rafael V. Nunes criticized earlier versions of the manuscript providing valuable suggestions that resulted in considerable improvement; Lucas Moreira for help with the English text; Felipe F. Curcio made very useful comments and reviewed the English version of this manuscript. This work was supported by grants provided by the Conselho Nacional de Desenvolvimento Científico e Tecnológico (CNPq - Programa Institucional de Bolsas de 
Iniciação Científica, 405697/2013-9, 302997/2013-0, 484035/ 2013-4, 202327/2013-2).

\section{References}

ARNAUD, P. 1982. Description de deux nouvelles espèces de Phanaeini. Miscellanea Entomologica 49:121-123.

ARNAUD, P. 1984. Nouveax Phanaeini (Col. Scarabaeidae). Miscellanea Entomologica 50:59-64.

ARNAUD, P. 1996. Description d'une nouvelle espèce de Phanaeus (Col. Scarabaeidae). Besoiro 3:6-7.

ARNAUD, P. 1996b. Description d'une nouvelle espèce de Coprophanaeus du Brésil (Col Scarabaeidae). Besoiro 2:6-7.

ARNAUD, P. 1997. Description de nouvelles espèces du Genre Coprophanaeus Ols. Besoiro 4:4-8.

ARNAUD, P. 2000. Description de nouvelles espèces de Phanaeides. (Col. Scarabaeidae). Besoiro 5:6-8.

ARNAUD, P. 2001. Description de nouvelles espèces de Phanaeides. Besoiro 6:2-8.

ARNAUD, P. 2002. Phanaeini. In Les Coléoptères du Monde. Hillside books, Canterbury, v. 28, p.1-151.

ARNAUD, P. 2002b. Description de nouvelles espèces de Phanaeides. (Col. Scarabaeidae). Besoiro 7:2-9.

ARNAUD, P. 2002c. Description de nouvelles espèces de Phanaeides. (Col. Scarabaeidae). Besoiro 8:2-5.

ARNAUD, P. 2004. Commentaires et mise au point synonymique dans le genre Oxysternon Laporte. Besoiro 10:10.

BATES, H.W. 1868. Notes on genera and species of Copridae. Coleopterologische Hefet. 4:87-91.

BATES, H.W. 1870. On a new genus and some new species of Copridae (Coleoptera-Lamellicornia). Transactions of the Royal Entomological Society of London 18:173-180, http://dx.doi.org/10.1111/ j.1365-2311.1870.tb01872.x

BRULLÉ, A. 1837. Histoire naturelle des insectes, comprenant leur classification, leurs moeurs et la description des espèces. Audouin M.V. \& Brullé A., Pillot F.D., Paris, France, v.6, p.1-448.

CASTELNAU. Le compte de [=F.L.N. de Laporte] 1840. Histoire naturelle des insects coléoptères. Duménil, Paris, France.

CUPELLO, M. \& VAZ-DE-MELLO, F.Z. 2013. Taxonomic Revision of the South American dung beetle genus Gromphas Brullé, 1837 (Coleoptera: Scarabaeidae: Scarabaeinae: Phanaeini: Gromphadina). Zootaxa 3722(4):439-482, http://dx.doi.org/10.11646/ zootaxa. 3722.4

CUPELLO, M. \& VAZ-DE-MELLO, F.Z. 2013b. New evidence for the validity of Coprophanaeus (C.) terrali Arnaud, 2002 (Coleoptera: Scarabaeidae: Scarabaeinae: Phanaeini), a dung beetle from Brazil. Zootaxa 3717(3):359-368.

EDMONDS, W.D. 1972. Comparative skeletal Morphology, Systematics and Evolution of the Phanaeine Dung Beetles. The University of Kansas Science Bulletin 49:731-874.

EDMONDS, W.D. 1994. Revision of Phanaeus Macleay, a New World Genus of Scarabaeine Dung Beetles (Coleoptera: Scarabaeidae, Scarabaeinae). Contribution in Science 443:1-105.

EDMONDS, W.D. \& ZÍDEK, J. 2004. Revision of the Neotropical Dung Beetle Genus Oxysternon (Scarabaeidae: Scarabaeinae: Phanaeini). Folia Heyrovskyana 11:1-58.

EDMONDS, W.D. \& ZÍDEK, J. 2010. A taxonomic review of the neotropical genus Coprophanaeus Olsoufieff, 1924 (Coleoptera: Scarabaeidae, Scarabaeinae). Insecta Mundi 129:1-111.

EDMONDS, W.D. \& ZÍDEK, J. 2012. Revised keys to and comments on species of the New World dung beetle genus Phanaeus MacLeay, 1819 (Coleoptera: Scarabaeidae: Scarabaeinae: Phanaeini). Insecta Mundi 274:1-108.

FABRICIUS, C. 1775. Systema Entomologiae... Officina Libraria Kortii, Flensburgi et Lipsiae.

GILLET, J.J.E. 1911. Scarabaeidae: Coprinae. In Coleopterorum Catalogus. I.W.Junk, Berlin, v.38, p.1-100.
GISTEL, J. 1857. Achthundert und zwanzig neue order unbeschriebene wirbellose Thiere. Straubing.

IBGE (Fundação Instituto Brasileiro de Geografia e Estatística). 1977. Geografia do Brasil: Região Norte, v.28, p.1-466p.

HALFFTER, G. \& FAVILA, M H. 1993. The Scarabaeinae (Insecta: Coleoptera), an animal group for analyzing, inventorying and monitoring biodiversity in tropical rainforest and modified landscapes. Biology International (27):15-21.

HALFFTER, G. \& MATTHEWS, E G. 1966. The natural history of dung beetles of the subfamily Scarabaeinae (Coleoptera: Scarabaeidae). Folia Entomologica Mexicana, (12):1-312.

HAROLD, E. 1868. Diagnosen neue coprophagen. Coleopterologische Hefte 4:79-86.

HOPE, F.W. 1838. Observations on the Lamellicorns of Olivier. The Entomological Magazine 5(4):312-326.

KLAGE, E.A. 1907. A wonderful new beetle of the group Copris. Entomological Society: 141-142.

KOHLMANN, B. \& SOLÍS, A. 2012. New species snd revalidations of scarab beetles (Coleoptera: Geotrupidae: Athyreini and Coleoptera: Scarabaeidae: Scarabaeinae) from Costa Rica and Panama. Zootaxa 3193:28-52.

KOLBE, H.J. 1905. Über die Lebensweise und die geographische Verbreitung der coprophagen Lamellicornier. Zoologischen Jahrbüchern 8: 475-594.

VAN LANSBERGE, G.W. 1874a. Ennearabdus gen. nov. Annales de la Société entomologique de Belgique (Comptes Rendus) 17: 143-144 (CXLIII-CXLIV).

VAN LANSBERGE, G.W. 1874b. Description de quelques Lamellicornes Coprophages. Coleopterologische Hefte 12(2):4-12.

LINNAEUS, C. 1767. Systema naturae... v. II, p.533-1327.

MACLEAY, W.S. 1819. Horae Entomologicae: or Essays on the annulose animals. Bagster S., London.

NEVINSON, B.G. 1890. Description of a new species of the genus Phanaeus MacLeay. Entomologists Monthly Magazine 26:1-315.

NICHOLS, E. SPECTOR, S. LOUZADA, J. LARSEN, T. AMEZQUITA, S. \& FAVILA, M.E. 2008. Ecological functions and ecosystem services provided by Scarabaeinae dung beetles. Biological Conservation 141:1461-1474, http://dx.doi.org/10.1016/j. biocon.2008.04.011

OLIVIER, G.A. 1789. Entomologie ou histoire naturelle des insects... Baudouin, Paris.

D'OLSOUFIEFF, G. 1924. Les Phanaeides. Insecta 13:4-172.

PERTY, M. 1830. Delectus Animalium Articulatorum quae in itinere per Brasilian... Inpensis Editoris, Monachii.

PHILIPS, T.K. EDMONDS, W.D. \& SCHOLTZ, C.H. 2004. A phylogenetic analysis of the New World tribe Phanaeini (Coleoptera: Scarabaeidae: Scarabaeinae): Hypotheses on relationships and origins. Insect Systematics \& Evolution 35:43-63.

PRICE, D.L. 2007. A phylogenetic analysis of the dung beetle genus Phanaeus (Coleoptera: Scarabaeidae) based on morphological data. Insect Systematics \& Evolution 38:1-18.

PRICE, D.L. 2009. Phylogeny and biogeography of the dung beetle genus Phanaeus (Coleoptera: Scarabaeidae). Systematic Entomology 34:137-150, http://dx.doi.org/10.1111/j.1365-3113.2008.00443.x

TARASOV, S. \& GÉNIER, F. 2015. Innovative and Parsimony Phylogeny of Dung Beetles (Coleoptera, Scarabaeidae, Scarabaeinae) Enhanced by Ontology-Based Partitioning of Morphological Characters. PLoS ONE 10(3):1-86, http://dx.doi.org/10.1371/journal.pone. 0116671

VAZ-DE-MELLO, F.Z. 1999. Scarabaeidae do estado de Roraima, Brasil. In IV Reunião latino-americana de Scarabaeoidologia (F.Z. Vaz-de-Mello, coord). UFV, Viçosa, p.78-79.

VAZ-DE-MELLO, F.Z. 2000. Estado atual de conhecimento dos Scarabaeidae s. str. (Coleoptera: Scarabaeiodea) do Brasil. In: Hacia un Proyecto CYTED para el Inventario y estimación de la diversidad entomológica en Iberoamérica: PrIBES-2000 (Martín-Piera F., Morrone J. J. \& Melic A., eds.). Sociedade Entomológica Aragonesa (SEA), Zaragoza, Spain, p.183-195. 
WATERHOUSE, C.O. 1891. New Scarabaeidae in the British Museum: a Fifth Contribution. The Annals and Magazine of natural History, including Zoology, Botany and Geology. London 6(8):53-61.

WEBER, F. 1801. Observationes Entomologicae, Continentes, Novorum quae condidit generum characteres, et Nuper detectarum specierum descriptiones. Kiliae Impensis bibliopolii academici novi, p.116.
ZUNINO, M. 1983. Las relaciones taxonómicas de los Phanaeina (Coleoptera, Scarabaeinae) y sus implicancias biogeográficas (Resumen). Revista Peruana de Entomologia 26(1):21-23.

ZUNINO, M. 1985. Las relaciones taxonomicas de los Phanaeina (Coleoptera, Scarabaeinae) y sus implicaciones biogeograficas. Folia Entomológica Mexicana 64:101-115.

Received 24/09/2014

Revised 25/05/2015

Accepted 29/05/2015 